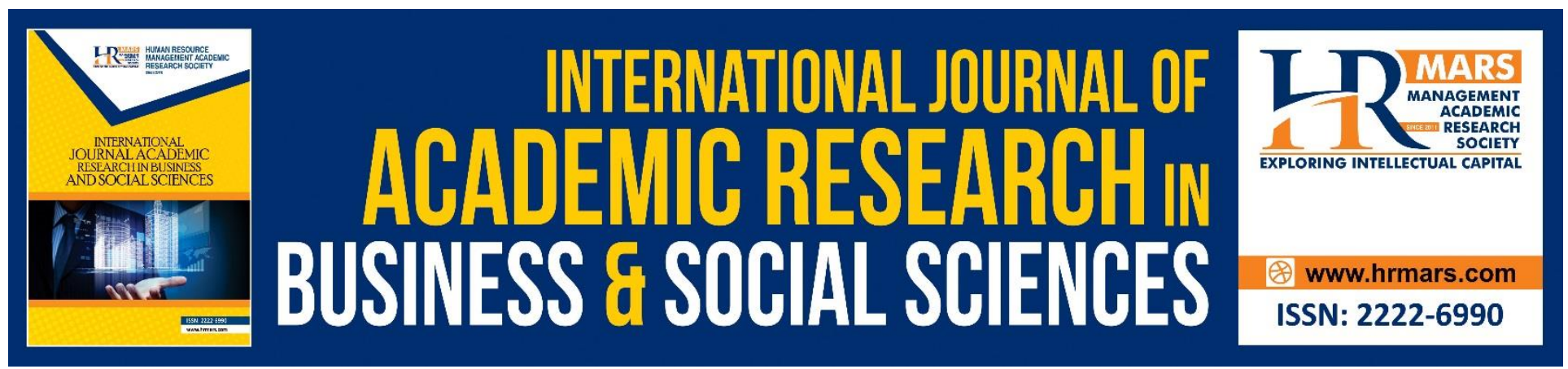

\title{
Residents' Perception on Health and Residential Value from Telecommunication Tower
}

\section{Norazmawati Md. Sani, Ahmad Fahmi Lim Bin Abdullah and Kai Xin Tay}

To Link this Article: http://dx.doi.org/10.6007/IJARBSS/v9-i1/5860 $\quad$ DOI: 10.6007/IJARBSS/v9-i1/5860

Received: 15 Nov 2018, Revised: 10 Dec 2019, Accepted: 01 Jan 2019

Published Online: 24 Jan 2019

In-Text Citation: (Sani, Abdullah, \& Tay, 2019)

To Cite this Article: Sani, N. M., Abdullah, A. F. L. Bin, \& Tay, K. X. (2019). Residents' Perception on Health and Residential Value from Telecommunication Tower. International Journal of Academic Research Business and Social Sciences, 9(1), 1288-1298.

\section{Copyright: (c) 2019 The Author(s)}

Published by Human Resource Management Academic Research Society (www.hrmars.com)

This article is published under the Creative Commons Attribution (CC BY 4.0) license. Anyone may reproduce, distribute, translate and create derivative works of this article (for both commercial and non-commercial purposes), subject to full attribution to the original publication and authors. The full terms of this license may be seen at: http://creativecommons.org/licences/by/4.0/legalcode

$$
\text { Vol. 9, No. 1, 2019, Pg. } 1288 \text { - } 1298
$$

Full Terms \& Conditions of access and use can be found at http://hrmars.com/index.php/pages/detail/publication-ethics 


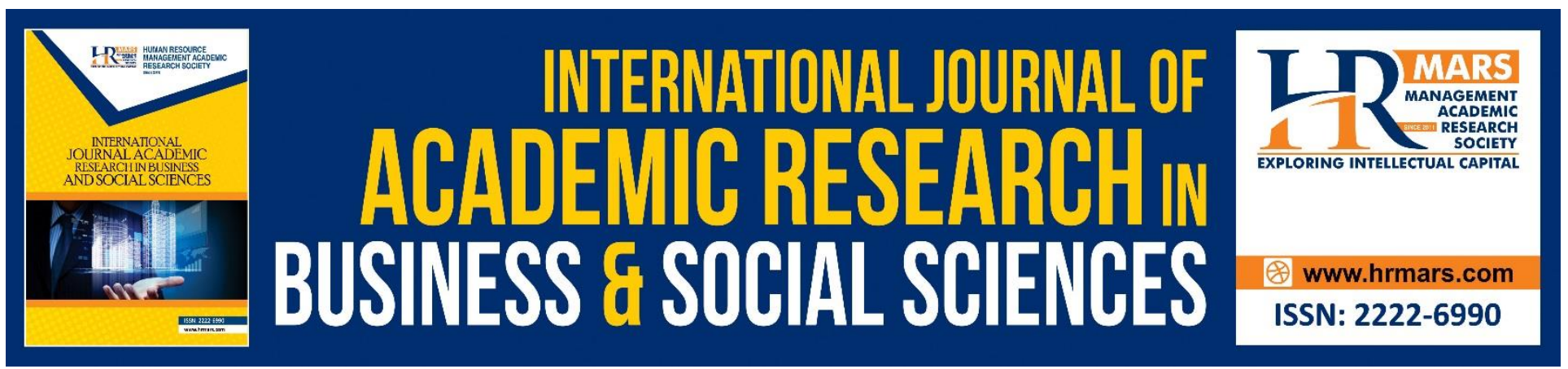

\title{
Residents' Perception on Health and Residential Value from Telecommunication Tower
}

\author{
Norazmawati Md. Sania ${ }^{*}$, Ahmad Fahmi Lim Bin Abdullah \\ and Kai Xin Tayc \\ ${ }^{a *}{ }^{*}$ School of Housing, Building and Planning, Universiti Sains Malaysia, 11800 Minden, Pulau \\ Pinang, Malaysia \\ Email: norazmawati@usm.my

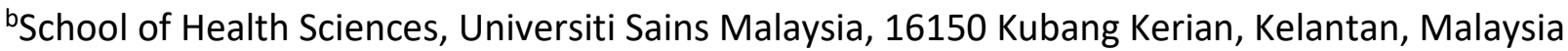 \\ Email: fahmilim@usm.my
}

\section{Abstract}

In last decades, due to the cellular phone systems and the rapid increase in the number of users of cellular phones, a growing concern about the possible health hazards has increased among public and scientists, particularly exposure to Electromagnetic Field (EMFs). Perceptions of appearance of telecommunication tower and its impacts were examined. Data from a face-to-face survey conducted in all states of Malaysia $(\mathrm{N}=509)$. The respondents were required to complete a standardized questionnaire that focused on the relevant psychological and psychobiological reactions measurement. Stata Software was used for statistical analysis using the Chi-square test with Fisher's exact and binomial logistic regression. The result shows that only one health symptom headache was statistically significant for both residents who live near to base station $(<300 \mathrm{~m})$ and those living far from base station $(>300 \mathrm{~m})$. The findings reveal that appearance of telecommunication tower is not influence the property price except one health symptom fatigue. The recommendations are also outlined in this paper.

Keywords: Telecommunication Base Station, Health Risk, Property Values, Residents' Perceptions, Chi-Square Test

\section{Introduction}

In this new era of globalisation, the use of mobile communication technologies for mobile phoning, texting, as well as now-mobile internet services has become a vital part of human life. Based on statistical data from (ITU, 2016a) global mobile penetration has increased approximately $126 \%$ in 2016 compared to the past 10 years, and mobile subscription is expected to further increase in the future. Technology advancement in Malaysia, especially in network performance (mobile broadband), devices (smart phone), and mobile services and applications (Web streaming, video 
INTERNATIONAL JOURNAL OF ACADEMIC RESEARCH IN BUSINESS AND SOCIAL SCIENCES Vol. 9, No. 1, Jan, 2019, E-ISSN: 2222-6990 @ 2019 HRMARS

surfing), has led to increasing demand for personal internet use, which has rose from $21.38 \%$ in 2000 to $78.79 \%$ in $(I T U, 2016 b)$.

To supply mobile data traffic for internet users, the ubiquitous mobile communication network infrastructure has widely expanded in Malaysia. The telecommunication companies have to build more base stations at strategic locations to ensure a high quality mobile network service to endusers, and to stay ahead of the competition from other service providers. Most of the base station siting locations are located in highly populated areas near residential areas, such as on the rooftops of shop lots and apartments, open spaces at playing fields, or parking lots of shopping complexes (Din, 2009). The number of telecommunication base stations built in residential areas has increased public concern due to substantial controversy about the potential hazard effects of the radiofrequency electromagnetic fields (EMF) emissions of base stations (D'Angelo et al., 2015; Isabona et al., 2016; Siegrist et al., 2005). According to Cousin and Siegrist, 2010; Hallberg and Oberfeld, 2006), the health effects of EMF are headaches, giddiness, nausea, skin rashes, feeling warn, depression, night sweats, memory loss, disturbances in menstruation, and insomnia. In addition, this may cause property values to diminish because the existence of these potential health effects. The increased media rendering to the potential health hazards of base stations has resulted a spread of public fear and therefore increase in residents' resistance to these base stations. This is due to the perceived adverse effects on health, aesthetics and property values in nearby these base stations. However, the extent to which factors affected the residents' decision to live nearby the base stations is not widely known in Malaysia. Many prior studies indicated that people living in the vicinity of telecommunication base stations suffer from adverse health conditions (Augner and Hacker, 2009). All of these studies have been empirically tested in other countries, but not in Malaysia. There are very few studies which investigate the impact of telecommunication base stations on residents' health and property value in Malaysia. The only existing study was conducted in Penang, Malaysia by Suleiman et al., (2014). Hence, this study aims to help fill the research void by including study sites in all the states in West Malaysia including Perlis, Kedah, Penang, Perak, Selangor, Kuala Lumpur, Negeri Sembilan, Melaka, Johor, Kelantan, Terengganu, and Pahang. The study determines residents' perceptions towards living proximity telecommunication base stations, its possible health effects of EMF and the property values.

\section{Experimental Details}

The positivist paradigm was selected for this research for the purpose of understanding the health impacts of EMF to residents living near telecommunication base station. The positivist paradigm was used to guide the research design, data collection, and data analysis, which are discussed in the following sections. Due to selecting positivism as the philosophical assumption for this research, quantitative method involving a survey questionnaire was employed. This approach was selected because this research bases its knowledge claims on pragmatic grounds; with respect to perceptions on health hazards and property values from living in the vicinity of the base station. The data collection started with the development of a survey instrument, aimed to establish a set of health symptoms that affect residents' perception on property values who living near base stations in West Malaysia. The questionnaire was designed as a self-administered survey. Next, the survey instrument 
was pilot-tested and then refined. The respondents are the residents who living near to the base station in selected Malaysia states (Kelantan, Penang, Kedah, Perlis, Selangor, Negeri Sembilan). The data collected during January to July 2017. Probability sampling was chosen as respondents were randomly selected from the sampling frame (total of residents) and each resident has a known, nonzero chance of being selected. The questionnaire included a set of questions on certain themes, respondents' profile, the characteristics of residence, and evaluative questions to gauge residents' perception on the impacts of base stations both health risks and property values. The primary data from the questionnaire survey were analysed using a descriptive, Chi-square and logistic regression analyses by the Stata 14 software.

The data were first analyzed by using chi-square tests to explore the single-dimensional relationship between the two group of respondents (those who feel base station affect the house price and those who were not) with categorized measurement items (distance, move out, aesthetic, and health symptoms). In the next stage, the binomial logit model was used to examine the difference between these two groups of respondents. The model proposed by McFadden, 1974a; McFadden (1974b) was adapted, whereby the choice of yes (coded 1) and no (coded 0 ) indicated that code 1 was those who felt base station affect the house price and code 0 was those who were not. McFadden's model relied on the assumption that the respondents who feel base station affect the house price are a nonrandom function, $V_{1}$ of the travel characteristics plus a random error term:

$$
T(\text { Yes }=1)=\mathrm{V}_{1}+\mathrm{e}_{1}
$$

On the other hand, the respondents who felt No as a random error term:

$$
T(\mathrm{No}=0)=\mathrm{V}_{0}+\mathrm{e}_{0}
$$

As a result, the measurement items (distance, move out, aesthetic, and health symptoms) related more to affect the house price rather than the otherwise if, and only if:

$$
\begin{gathered}
T(\text { Yes }=1)>\mathrm{T}(\mathrm{No}=0) \\
\text { Or } \\
\mathrm{V}_{1}-\mathrm{V}_{0}>\mathrm{e}_{0}-\mathrm{e}_{1}
\end{gathered}
$$

In the case of the distributions of $e_{0}$ and $e$, the probability that Yes $=1$ was

$$
P(\text { Yes }=1)=\exp \left(V_{1}\right) /\left[\exp \left(V_{1}\right)+\exp \left(V_{0}\right)\right]
$$

However, if case 1 was unable to estimate the absolute levels of the parameters of $V_{1}$, it would be able to estimate the measurement variable parameters of the respondents felt base station affect the house price relative to those who felt not affect the house price. This was known as the log odds $i$ of occurrence on Yes over No, as expressed by the function:

Then,

$$
\mathrm{V}_{1}-\mathrm{V}_{0}=\mathrm{b}_{0}+\sum \mathrm{b}_{\mathrm{j}} \mathrm{x}_{\mathrm{j}}
$$

$$
\begin{gathered}
P(\text { Yes }=1)=\exp \left(b_{0}+\sum b_{j} x_{j}+V_{0}\right) /\left[\exp \left(b_{0}+\sum b_{j} x_{j}+V_{0}\right)+\exp \left(V_{0}\right)\right]--- \text { with parameters } V_{1} \\
\text { Or } \\
P(\text { Yes }=1)=\exp \left(b_{0}+\sum b_{j} x_{j}\right) /\left[\exp \left(b_{0}+\sum b_{j} x_{j}\right)+1\right]------------ \text { without parameters } V_{1}
\end{gathered}
$$

Then, dividing the numerator and denominator by $\exp \left(b_{0}+\sum b_{j} x_{j}\right)$ yields the logit model as:

$$
P(\text { Yes }=1)=1 /\left[1+\exp \left(-\left(b_{0}+\sum b_{j} x_{j}\right)\right)\right]
$$


Therefore, the logit model in equation (1) showed the probability of the intra-safe/unsafe to live, where the measurement variable $x_{j}$ included the demographic, type of resident, awareness, and health symptoms. This logit equation was used to run the logistic regression analysis in Stata software 14.2. The Hosmer-Lemeshow test was used for the goodness of fit test. Additionally, the vector of the coefficient $b_{j}$ was estimated by the maximum likelihood. For measuring the goodness of fit of the equation, McFadden, 1974a; McFadden (1974b) suggested the use of the likelihood ratio index:

$$
1-L_{U R} / L_{R} \text {, }
$$

where LUR was the unrestricted vector of the log-likelihood function at the maximum likelihood estimation of the parameters $b_{j}$, while $L_{R}$ was the value of the likelihood function when all the parameters were restricted to zero (Reece, 2004).

\section{Results and Discussion}

\section{Descriptive analyses}

The summary statistics of the respondents' background profile are presented in Table 1 . The majority of respondents were male, aged 25-35 years old, married, with secondary school education level, and general employees in Malaysia. For the residential area, 162 respondents are living or working near the base station in Penang, 161 respondents in Perlis, 86 respondents in Kedah, 60 respondents in Kelantan, and 20 respondents each in Selangor and Negeri Sembilan. There are three types of residency 81 respondents living in single unit house (Bungalow), 353 respondents staying in terrace house type, and 75 respondents living in Semi-detached house. In total, 509 respondents comprise 172 house owners, 225 renters, and 108 inheritors. Descriptive statistics of the variables are listed in Table 2, which shows the variable names, means and standard deviation. The mean of length of stay (LOS) is 2.83 with a standard deviation of 1.03. Low value of standard deviation (SD) indicates that most of the numbers are much closed to average or mean. Majority of respondents are living in proximity to base station more than 10 years (33.79\%). The mean value of distance to base station (DIS) is 2.68, implying that most of the respondents' houses are located more than $100 \mathrm{~m}$ away from the base station. Two third of respondent think the base stations are not influence the property values (mean $=1.24, \mathrm{SD}=1.14$ ). Majority of respondents would not move away even if there is base station nearby (mean $=1.85, \mathrm{SD}=0.35$ ). However, the respondent agreed that base station affect the property aesthetic (mean $=1.25, \mathrm{SD}=0.43$ ). All of the health symptoms have high mean value (mean $=>1.50$ ), explaining that more than half respondents did not experience these symptoms. 
INTERNATIONAL JOURNAL OF ACADEMIC RESEARCH IN BUSINESS AND SOCIAL SCIENCES Vol. 9, No. 1, Jan, 2019, E-ISSN: 2222-6990 C 2019 HRMARS

Table 1: Respondent Profiles

\begin{tabular}{|c|c|c|}
\hline \multicolumn{3}{|c|}{ SOCIODEMOGRAPHIC } \\
\hline Profile & Frequency & Percent (\%) \\
\hline \multicolumn{3}{|l|}{ Gender } \\
\hline Male & 275 & 54 \\
\hline Gender & 234 & 46 \\
\hline \multicolumn{3}{|l|}{ Age } \\
\hline 19-24 years & 124 & 24 \\
\hline $25-35$ years & 136 & 26 \\
\hline $36-45$ years & 117 & 23 \\
\hline More than 45 years & 132 & 26 \\
\hline \multicolumn{3}{|l|}{ Marital status } \\
\hline Single & 186 & 37 \\
\hline Married & 302 & 59 \\
\hline Widow & 21 & 4 \\
\hline \multicolumn{3}{|l|}{ Education level } \\
\hline Primary school & 50 & 10 \\
\hline Secondary school & 191 & 38 \\
\hline High school & 189 & 37 \\
\hline Diploma/Degree & 16 & 3 \\
\hline Master/PhD & 9 & 2 \\
\hline No formal Education & 54 & 11 \\
\hline \multicolumn{3}{|l|}{ Occupational sector } \\
\hline Management & 71 & 14 \\
\hline Engineering & 27 & 5 \\
\hline Medical & 19 & 4 \\
\hline Education & 46 & 9 \\
\hline Employees & 227 & 45 \\
\hline Unemployed & 119 & 23 \\
\hline \multicolumn{3}{|l|}{ Region } \\
\hline Penang & 162 & 32 \\
\hline Perlis & 161 & 32 \\
\hline Kedah & 86 & 17 \\
\hline Kelantan & 60 & 12 \\
\hline Selangor & 20 & 4 \\
\hline Negeri Sembilan & 20 & 4 \\
\hline \multicolumn{3}{|l|}{ Type of residency } \\
\hline Single Unit Houses & 81 & 16 \\
\hline Terrace & 353 & 69 \\
\hline Semi Detached & 75 & 15 \\
\hline \multicolumn{3}{|c|}{ House Ownership status } \\
\hline Own & 176 & 35 \\
\hline Renting & 225 & 44 \\
\hline Inherit & 108 & 21 \\
\hline
\end{tabular}


INTERNATIONAL JOURNAL OF ACADEMIC RESEARCH IN BUSINESS AND SOCIAL SCIENCES Vol. 9, No. 1, Jan, 2019, E-ISSN: 2222-6990 @ 2019 HRMARS

Table 2: Variables Themes and Summary Statistics

\begin{tabular}{|c|c|c|c|}
\hline Variable & Characteristics & Mean & $\begin{array}{l}\text { Standard } \\
\text { Deviation }\end{array}$ \\
\hline $\begin{array}{l}\text { Distance to base } \\
\text { station (DIS) }\end{array}$ & $\begin{array}{l}1=\text { distance from base station less than } 100 \mathrm{~m} \\
2=\text { distance from base station } 101-200 \mathrm{~m} \\
3=\text { distance from base station } 201-300 \mathrm{~m} \\
4=\text { distance from base station more than } 300 \mathrm{~m}\end{array}$ & 2.68 & 1.14 \\
\hline Property price & $\begin{array}{l}1 \text { if respondent think the base station would NOT influence the house } \\
\text { price, } 0 \text { otherwise }\end{array}$ & 1.24 & 0.43 \\
\hline Move out & 1 if respondent plan to move out due to base station, 0 otherwise & 1.85 & 0.35 \\
\hline Aesthetic & 1 if respondent think base station affect house aesthetic, 0 otherwise & 1.25 & 0.43 \\
\hline \multicolumn{4}{|l|}{ Health Symptoms } \\
\hline Headache & 1 if respondent experience it, 0 otherwise & 1.68 & 0.47 \\
\hline Fatigue & 1 if respondent experience it, 0 otherwise & 1.67 & 0.47 \\
\hline $\begin{array}{l}\text { Nausea and } \\
\text { vomiting }\end{array}$ & 1 if respondent experience it, 0 otherwise & 1.97 & 0.22 \\
\hline Sight problem & 1 if respondent experience it, 0 otherwise & 1.87 & 0.34 \\
\hline Skin problems & 1 if respondent experience it, 0 otherwise & 1.94 & 0.24 \\
\hline Loss of appetite & 1 if respondent experience it, 0 otherwise & 1.93 & 0.26 \\
\hline Nose bleed & 1 if respondent experience it, 0 otherwise & 1.97 & 0.17 \\
\hline
\end{tabular}

\section{Chi-Square Analysis}

Table 3 provides the Chi-square results to examine whether these variables are associated with the DIS. The results show that move out, aesthetics, and health symptom headache are found statistically significant associate with DIS (P-value $<0.05)$. The Chi-square between move out and DIS $\left(X^{2}(3)=\right.$ 9.604, P-value $=0.02)$, between aesthetic and DIS $\left(X^{2}(3)=18.442\right.$, P-value $\left.=0.00\right)$, and between headache and DIS $\left(X^{2}(3)=15.479\right.$, P-value $\left.=0.00\right)$. The other variables are found not statistically significant associate with DIS.

Table 3: Chi-Square Results of the Influences of Variables Living In Proximity of Base Station

\begin{tabular}{|l|l|l|l|}
\hline Variables & $\mathbf{X}^{\mathbf{2}}$ & $\mathbf{d f}$ & P value \\
\hline To DIS & \multicolumn{1}{|l|}{} \\
\hline Property price & 4.995 & 3 & 0.172 \\
\hline Move out & 9.604 & 3 & $0.022^{*}$ \\
\hline Aesthetic & 18.442 & 3 & $0.000^{*}$ \\
\hline Health Symptoms & \multicolumn{5}{|l|}{} \\
\hline Headache & 15.479 & 3 & $0.001^{*}$ \\
\hline Fatigue & 6.350 & 3 & 0.096 \\
\hline Nausea and vomiting & 6.632 & 3 & 0.085 \\
\hline Sight problem & 5.291 & 3 & 0.152 \\
\hline Skin problems & 4.116 & 3 & 0.249 \\
\hline Loss of appetite & 2.163 & 3 & 0.539 \\
\hline Nose bleed & 2.569 & 3 & 0.463 \\
\hline
\end{tabular}

* Significance level at $\mathrm{P}<0.05$ 
INTERNATIONAL JOURNAL OF ACADEMIC RESEARCH IN BUSINESS AND SOCIAL SCIENCES

Vol. 9, No. 1, Jan, 2019, E-ISSN: 2222-6990 @ 2019 HRMARS

\section{Logistic Regression Analysis}

Due to the weakness in the statistical power of the chi-square test as it is a non-parametric test, binomial logistic regression analysis was selected as a more understandable approach for this study (Table 4). The first column of Table 4 showed the coefficient bj of equation (1), the standard errors associated with the coefficients, the Wald statistic or Wald chi-square value together with the 2-tailed $\mathrm{p}$-value, and the odds ratio or exponential of the coefficients. In assessing the model fit, two statistical tests were applied to assess the significance of the binomial logit model. Hosman-Lemeshow statistic of overall fit indicated that there was no significant difference between the actual and predicted classifications, where the $p$-value $>0.05$ [0.3395]. The likelihood ratio index measure of the goodness of fit of the estimated equation was 0.044 . These two statistics provided good support for the logit model.

The fourth column showed the $p$-value for these parameters (Table 4). There were only two items found to be significant to the predictive ability of the model: aesthetic $(p=0.003)$ and fatigue $(p=0.025)$. The odds of the residents felt fatigue living near to base station was 0.574 , value less than 1. This expressed that these respondents were less likely to think the base station would affect the property price. Significant results were observed in the respondents who felt aesthetic would affect the property value with a p-value of 0.00 , and the odds ratio obtained for this variable (2.029) was more than 1 . This indicated that residents who selected these items were more likely to agree that base station was affecting the property value (see also Pallant (2010), p. 175-178, for further explanation on the $p$-value and odd ratio of the binomial logit model analysis). 
INTERNATIONAL JOURNAL OF ACADEMIC RESEARCH IN BUSINESS AND SOCIAL SCIENCES Vol. 9, No. 1, Jan, 2019, E-ISSN: 2222-6990 @ 2019 HRMARS

Table 4: Logistic Regression Test

\begin{tabular}{|c|c|c|c|c|c|}
\hline \multirow[t]{2}{*}{ Item toward property value } & Coefficient & \multirow{2}{*}{$\begin{array}{l}\text { Standard } \\
\text { error }\end{array}$} & \multirow{2}{*}{$\begin{array}{l}\text { Wald } \\
\text { statistic }\end{array}$} & \multirow[t]{2}{*}{ P-value } & \multirow[t]{2}{*}{ Odd ratio } \\
\hline & $b_{j}$ & & & & \\
\hline \multicolumn{6}{|l|}{ Distance to base station (DIS) } \\
\hline $101-200 m$ & -0.291 & 0.329 & -0.88 & 0.377 & 0.748 \\
\hline $201-300 m$ & 0.144 & 0.351 & 0.41 & 0.682 & 1.155 \\
\hline$>301 \mathrm{~m}$ & -0.321 & 0.309 & -1.04 & 0.299 & 0.725 \\
\hline Move out & -0.032 & 0.270 & -0.12 & 0.905 & 0.968 \\
\hline Aesthetic & 0.707 & 0.235 & 3.01 & $0.003^{* *}$ & 2.029 \\
\hline \multicolumn{6}{|l|}{ Health symptoms } \\
\hline Headache (No) & 0.309 & 0.228 & 1.35 & 0.176 & 1.362 \\
\hline Fatigue (No) & 0.556 & 0.247 & -2.25 & $0.025^{*}$ & 0.574 \\
\hline Nausea vomiting (No) & -0.022 & 0.495 & -0.05 & 0.964 & 0.978 \\
\hline Sight problem (No) & -0.030 & 0.334 & -0.09 & 0.929 & 0.970 \\
\hline Skin problem (No) & 0.651 & 0.421 & 1.55 & 0.122 & 1.918 \\
\hline Loss of appetite (No) & 0.237 & 0.413 & 0.57 & 0.567 & 0.629 \\
\hline Nosebleed (No) & -0.464 & 0.696 & -0.67 & 0.505 & 1.267 \\
\hline $\begin{array}{l}\text { Number of Obs } \\
\text { Hosmer \& Lemeshow }\end{array}$ & \multirow{3}{*}{\multicolumn{2}{|c|}{$\begin{array}{l}509 \\
\\
9.03(8) \\
\mathbf{0 . 3 3 9 5} \\
\end{array}$}} & & & \\
\hline Chi-square (df) & & & & & \\
\hline$p$-value & & & & & \\
\hline LUR & -268.829 & & & & \\
\hline$L_{R}$ & -281.187 & & & & \\
\hline $1-L_{U R} / L_{R}$ & 0.044 & & & & \\
\hline
\end{tabular}

${ }^{*} p<0.05, * * p<0.01$

\section{Conclusion}

The present study examined residents' perceptions on the health impacts of telecommunication base stations in Malaysia, as well as its impacts on property value. The analysis showed that the significant variables that associate with the distance away from the base station are move out decision, aesthetics impact, and health symptom of headache. The existence of a base station in a specific area would not cause residents to move away from the area as result discloses that $85 \%$ of respondents would not move out, which may be due to the increasing trend in Malaysian housing prices (Mariadas et al., 2016). This study confirmed the study of Filippova and Rehm, (2011) that there is not statistically significant between impacts of base station and property value and the visually disruptive of base station found negatively affecting the property values.

The finding regards the health symptom is different with the study of Suleiman et al., 2014; AbdelRassoul et al., 2007; Mohler et al., 2010) which their findings revealed that fatigue, sight problem, and loss of appetite are the negative health risks of living proximity of base station. However, this present study found only one health symptom headache experienced by adjacent residents of base station. The authorities should not neglect this issue, even if there are only one health symptom headache experienced by residents who living nearby the base station. To reduce the intensity of RF, telecommunication companies should consider sharing base stations to mount their transceivers 
INTERNATIONAL JOURNAL OF ACADEMIC RESEARCH IN BUSINESS AND SOCIAL SCIENCES Vol. 9, No. 1, Jan, 2019, E-ISSN: 2222-6990 @ 2019 HRMARS

rather than increase the number of towers. As study of Brandt and Maenning, 2012) discovered that individual antenna have less effect than group of antenna masts.

More specifically, binomial logistic regression was used and it discovered that only the base station's aesthetic was not affects the property value, and surprising that resident who felt fatigue would think it influence the property value. Local authorities should regulate base station construction to strictly follow the guidelines provided by the Institute of Electrical and Electronics Engineers (IEEE) (1999) and the International Commission on Non-Ionizing Radiation Protection (ICNIRP) (1998). It is also recommended that the $\mathrm{MCMC}$ conduct random audits to ensure that the wireless communication environment conforms to the EMF safety level. Furthermore, the MCMC should openly disclose details on the localities of each telecommunication base station, including the names of the telecommunication companies operating them, on an official website. This will not only encourage transparency but can also avoid the build and operation of illegal base stations. Other than that, public opinion should be considered before construction of base stations rather than face protest after the base station has been built.

\section{Acknowledgements}

Much appreciation is extended to the Ministry of Higher Education Fundamental Research Grant Scheme (FRGS) with the account number 203/PPBGN/6711518, USM members and those involved in this study.

\section{References}

Abdel-Rassoul, G., El-Fateh, O. A., Salem, M. A., Michael, A., Farahat, F., El-Batanouny, M., \& Salem, E. (2007). Neurobehavioral effects among inhabitants around mobile phone base stations. NeuroToxicology, 28(2), 434-440. https://doi.org/10.1016/j.neuro.2006.07.012

Augner, C., \& Hacker, G. (2009). Are people living next to mobile phone base stations more strained? Relationship of health concerns, self-estimated distance to base station, and psychological parameters. Indian Journal of Occupational and Environmental Medicine, 13(3), 141. https://doi.org/10.4103/0019-5278.58918

Cousin, M., \& Siegrist, M. (2010). Risk perception of mobile communication: a mental models approach. Journal of Risk Research, 13(5), 599-620.

https://doi.org/10.1080/13669870903236751

Brandt, S., \& Maennig, W. (2012). Perceived externalities of cell phone base stations: The case of property prices in Hamburg, Germany. Environment and Planning A, 44(2), 396-410. https://doi.org/10.1068/a44292\

D'Angelo, C., Costantini, E., Kamal, M. A., \& Reale, M. (2015). Experimental model for ELF-EMF exposure: Concern for human health. Saudi Journal of Biological Sciences, 22(1), 75-84. https://doi.org/10.1016/j.sjbs.2014.07.006

Din, N. M. (2009). Radio Frequency Radiation Study. Retrieved March 30, 2018, from rfemf.mcmc.gov.my/skmmgovmy/.../Radio-Frequency-Radiation-Study_Uniten.pdf

Filippova, O., \& Rehm, M. (2011). The impact of proximity to cell phone towers on residential property values. International Journal of Housing Markets and Analysis, 4(3), 244-267. 
INTERNATIONAL JOURNAL OF ACADEMIC RESEARCH IN BUSINESS AND SOCIAL SCIENCES

Vol. 9, No. 1, Jan, 2019, E-ISSN: 2222-6990 @ 2019 HRMARS

https://doi.org/10.1108/17538271111153022

Hallberg, O., \& Oberfeld, G. (2006). Letter to the editor: Will we all become electrosensitive? Electromagnetic Biology and Medicine, 25(3), 189-191.

Isabona, J., Srivastava, V. M., \& Robert, O. O. (2016). Spatial variation of the electromagnetic radiations due to exposure to telecommunication base station transmitters in a pilot region. International Journal of Applied Engineering Research, 11(22), 10994-11001.

ITU. (2016a). ICT Facts and Figures: Mobile-cellular subscriptions. Retrieved March 30, 2018, from https://www.itu.int/en/ITU-D/Statistics/Pages/stat/default.aspx

ITU. (2016b). ICT Facts and Figures: Percentage of Individuals using the Internet. Retrieved March 30, 2018, from https://www.itu.int/en/ITU-D/Statistics/Pages/stat/default.aspx

Mariadas, P. A., Selvanathan, M., \& Hong, T. K. (2016). A Study on Housing Price in Klang Valley, Malaysia. International Business Research, 9(12), 103. https://doi.org/10.5539/ibr.v9n12p103

McFadden, D. (1974a). Condition logit analysis of qualitative choice behavior. In Frontiers in Econometrics (Vol. 1, pp. 105-143). https://doi.org/10.1108/eb028592

McFadden, D. (1974b). The measurement of urban travel demand. Journal of Public Economics. https://doi.org/10.1016/0047-2727(74)90003-6

Mohler, E., Frei, P., Braun-Fahrländer, C., Fröhlich, J., Neubauer, G., \& Röösli, M. (2010). Effects of everyday radiofrequency electromagnetic-field exposure on sleep quality: a cross-sectional study. Radiation Research, 174(3), 347-356. https://doi.org/10.1667/RR2153.1

Shahbazi-Gahrouei, D., Karbalae, M., Moradi, H. A., \& Baradaran-Ghahfarokhi, M. (2014). Health effects of living near mobile phone base transceiver station (BTS) antennae: A report from Isfahan, Iran. Electromagnetic Biology and Medicine, 33(3), 206-210.

https://doi.org/10.3109/15368378.2013.801352

Siegrist, M., Earle, T. C., Gutscher, H., \& Keller, C. (2005). Perception of mobile phone and base station risks. Risk Analysis, 25(5), 1253-1264. https://doi.org/10.1111/j.1539-6924.2005.00672.x

Suleiman, A., Gee, T. T., \& Krishnapillai, A. D. (2014). Electromagnetic Radiation Health Effects in Exposed and Non-Exposed Residents in Penang, (April), 77-83.

https://doi.org/10.4236/gep.2014.22012 